\title{
The importance of central-visual perception disorders for dyslexia and dyscalculia
}

\author{
Kucian, Karin
}

\begin{abstract}
Visual perception disorders can lead to different learning disorders in children. These are often difficulties in reading and writing, as well as in calculation and number processing. Dyslexia, the specific reading and spelling disorder, is also associated with various deficits of visual perception which, for example, make it difficult to distinguish between individual letters or impair the text-dependent eye movements. From a neural point of view, the visual word form area (VWFA) in the fusiform gyrus, which is responsible for the visual processing of orthographic information must be highlighted, since the VWFA is often disturbed in dyslexics. Dyscalculia, the specific calculation disorder, is often associated with difficulties in visual-spatial processing. This is not surprising since our mental representation of numbers and magnitudes is spatially organized. This means we have a kind of mental number line on which we store numbers according to their magnitude. In the case of dyscalculia, the construction and the automated access to this mental number line are often disturbed. This mental number line is located in the intraparietal sulcus (IPS) of the brain, the region which shows increased abnormalities in dyscalculia, such as volume differences of gray matter, reduced activation or reduced connection to other cortical areas. Although central-visual perception disorders can clearly lead to learning disabilities of reading and writing, as well as calculation, dyslexia or dyscalculia is defined only when organic causes can be ruled out, which is why a differentiation between classical dyslexia or dyscalculia and problems in reading/writing and calculation due to visual deficits is necessary.
\end{abstract}

DOI: https://doi.org/10.1055/s-0037-1602891

Other titles: Die Bedeutung der ZVWS für die Dyslexie und Dyskalkulie

Posted at the Zurich Open Repository and Archive, University of Zurich

ZORA URL: https://doi.org/10.5167/uzh-138256

Conference or Workshop Item

Published Version

Originally published at:

Kucian, Karin (2017). The importance of central-visual perception disorders for dyslexia and dyscalculia. In: Neuropädiatrics 2017, Bad Nauheim, 27 April 2017 - 30 April 2017. Georg Thieme Verlag, S1-S45. DOI: https://doi.org/10.1055/s-0037-1602891 
- EN

- $\overline{\mathrm{DE}}$

- Home

- Produkte

- Zeitschriften

- Bücher

- Buchreihen

- Hilfe

- Kontakt

- $\underline{\text { Portal }}$

Neuropediatrics

Suche

Volltextsuche

- Volltextsuche

- Autorensuche

- Titelsuche

- DOI-Suche

- Metadatensuche

Daten absenden

- Autoren

- Autorenhinweise

- Manuskript einreichen

- Abonnement

- Ihr Abonnement: Kontakt \& Information

- Lizenzen: Kontaktpartner Institutionen

- Gesellschaft für Neuropädiatrie

o Offizielles Organ der Gesellschaft für Neuropädiatrie

- Stellenmarkt

$\circ$ Aktuelle Stellenangebote

- nicht eingeloggt Login

- Benutzername:

Passwort:

Login

Passwort vergessen? Neu registrieren

$\underline{\text { Warenkorb }}$ 
UZH Hauptbibliothek / Zentralbibliothek Zürich

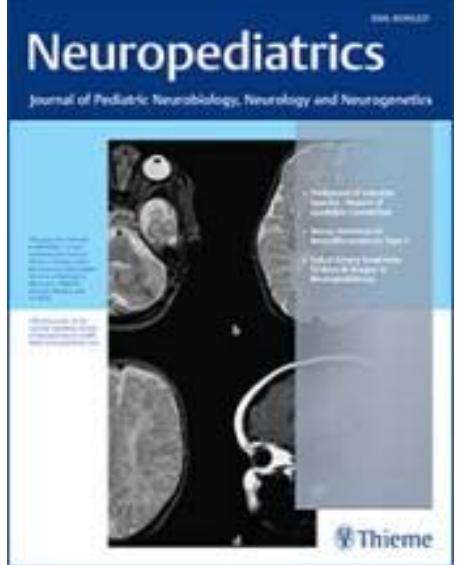


Jahr

2017

- 2018

- 2017

- 2016

- 2015

- 2014

- 2013

- 2012

- 2011

- 2010

- 2009

- 2008

- 2007

- 2006

- 2005

- 2004

- 2003

- 2002

- 2001

- 2000

- 1999

- 1998

- 1997

- 1996

- 1995

- 1994

- 1993

- 1992

- 1991

- 1990

- 1989

- 1988

- 1987

- 1986

- 1985

- 1984

- 1983

- 1982

- 1981

- $\underline{1980}$

- 1979

- 1978

- 1977

- 1976

- 1975

- 1974

- 1973

- 1972

- 1971

- $\underline{1970}$

- $\overline{1969}$ 
Ausgabe

- 06: 403-486

- 05: 323-402

- 04: Neuromuscular Disorders in Children and Adolescents

- 03: 133-208

- $02: 61-132 \mid \mathrm{v}$

- $01: 1-60$

- $\underline{\text { S 01: e1 }}$ Abstracts of the 43rd Annual Meeting of the Society ...

- Inhaltsverzeichnis

- aktuelle Ausgabe

- Probeausgabe (01/2018)

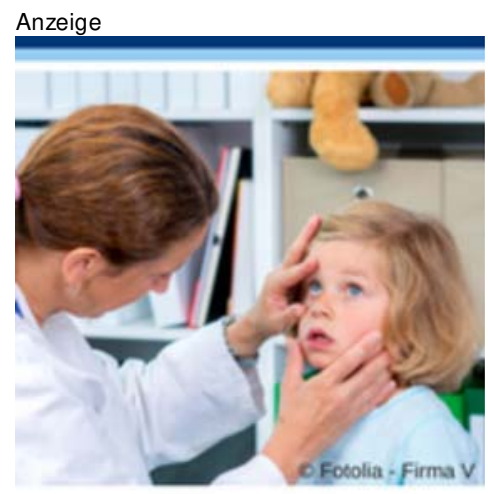

Diese seltene angeborene

Stoffwechselerkrankung wird oft jahrelang nicht diagnostiziert!

\section{Mehr erfahren Jü}

Ähnliche Zeitschriften

Journal of Neurological Surgery

$\bullet$

Indian Journal of Neurosurgery

Indian Journal of Neurotrauma

European Journal of Pediatric Surgery

Current Research: Concussion Journal of Child Science

-

$\underline{\text { International Journal of Epilepsy }}$

Bücher zum Thema

$\underline{\text { Neurologie }}$ 


\section{Pädiatrie}

\section{Neurochirurgie}

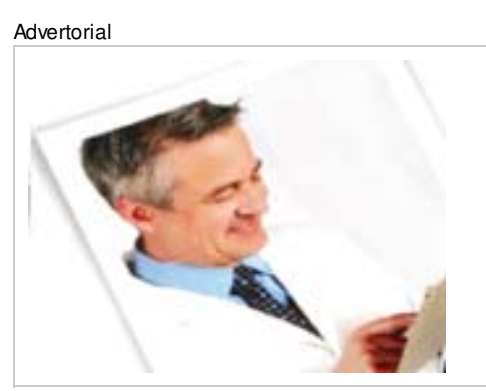

Thieme Medizinjobs Cross-Media-Pakete: Print, Online, Digital

Vom Anästhesiologen über MTRAs bis hin zu Gesundheits- und Pflegekräften erreichen

wir ärztliche und pflegerische Fachkräfte. Wir bieten Ihnen individuelle Cross-Media-

Pakete für eine streuverlustfreie Kandidatenansprache von

aktiv-suchenden und nicht-aktiv-suchenden-Bewerbern.

Hier geht es zu unseren Mediadaten $>>$

\section{Teilen / Bookmarken}

Facebook Twitter Linkedin Google+ Weibo CiteULike

Neuropediatrics 2017; 48(S 01): S1-S45

DOI: $10.1055 / \mathrm{s}-0037-1602891$

KSS - Key Subject Session

Georg Thieme Verlag KG Stuttgart · New York

\section{The Importance of Central-Visual Perception Disorders for Dyslexia and Dyscalculia}

\section{K. Kucian}

Center for MR Research, University Children's Hospital Zurich, Zurich, Switzerland

, Institutsangaben

Weitere Informationen

\section{Publikationsverlauf}

Publikationsdatum:

26.April 2017 (online)

- Kongressbeitrag

- $\underline{\text { Volltext }}$

Visual perception disorders can lead to different learning disorders in children. These are often difficulties in reading and writing, as well as in calculation and number processing.

Dyslexia, the specific reading and spelling disorder, is also associated with various deficits of visual perception which, for example, make it difficult to distinguish between individual letters or impair the text-dependent eye movements. From a neural point of view, the visual word form area (VWFA) in the fusiform gyrus, which is responsible for the visual processing of orthographic information must be highlighted, since the VWFA is often disturbed in dyslexics.

Dyscalculia, the specific calculation disorder, is often associated with difficulties in visual-spatial processing. This is not surprising since our mental representation of numbers and magnitudes is 
spatially organized. This means we have a kind of mental number line on which we store numbers according to their magnitude. In the case of dyscalculia, the construction and the automated access to this mental number line are often disturbed. This mental number line is located in the intraparietal sulcus (IPS) of the brain, the region which shows increased abnormalities in dyscalculia, such as volume differences of gray matter, reduced activation or reduced connection to other cortical areas.

Although central-visual perception disorders can clearly lead to learning disabilities of reading and writing, as well as calculation, dyslexia or dyscalculia is defined only when organic causes can be ruled out, which is why a differentiation between classical dyslexia or dyscalculia and problems in reading/writing and calculation due to visual deficits is necessary.

\#

Die Autoren geben an, dass kein Interessenkonflikt besteht.

\section{zum Seitenanfang}

(C) 2018 Georg Thieme Verlag KG | Impressum | Datenschutz | Smartphone Version Ihre aktuelle IP-Adresse: 130.60.47.161

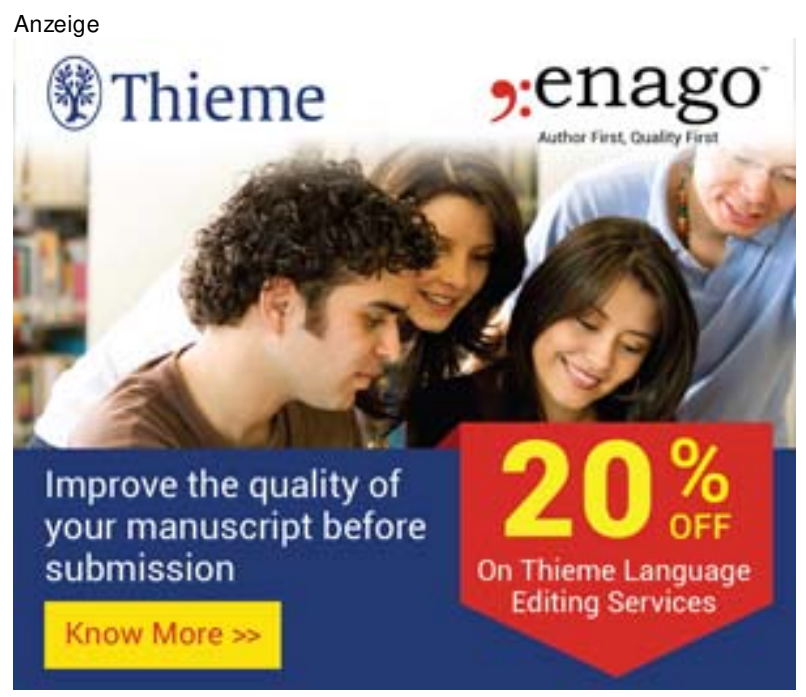

Anzeige 


\section{Warten Sie nicht zu lange...}

Nur bis 28.02. Fachzeitschriften im Angebot

\section{Jetzt bestellen!}
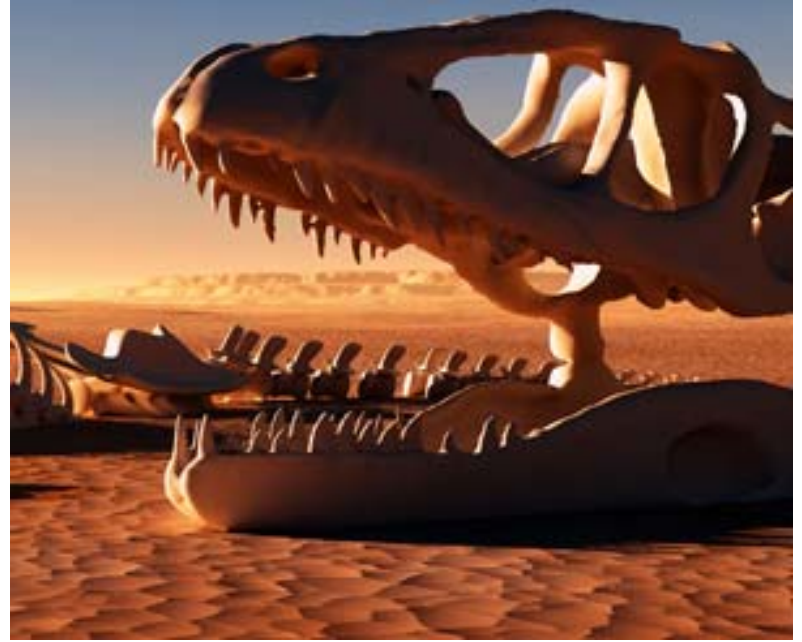